\title{
Natural Waste to Electricity: Engineering Pomegranate Peels and Ag-Doped ZnO for Photovoltaic Applications
}

Vincent Joseph Kanniyambatti Lourdusamy ( $\sim$ chemvin@hotmail.com )

Chennai Institute of Technology https://orcid.org/0000-0002-0898-8119

Mary Rosana Nalzala Thomas

Rajalakshmi Engineering College

Vijai Anand Kabali

Sathyabama Institute of Science and Technology

Dhilip Kumar Rajaiah

Chennai Institute of Technology

\section{Research Article}

Keywords: Natural waste to electricity, Natural dye, Nanoparticles, DSSC, Ag doped ZnO, Photovoltaic applications, Current-Voltage characteristics

Posted Date: August 9th, 2021

DOI: https://doi.org/10.21203/rs.3.rs-626898/v1

License: (9) This work is licensed under a Creative Commons Attribution 4.0 International License. Read Full License 


\section{Abstract}

Utilization of natural waste for energy conversion offers the method for clean energy production with sustainable development. The pomegranate peels are the natural waste generated every day and we describe the conversion of this waste into electricity by a simple and cost-effective method. Dye Sensitized Solar Cells (DSSCs) offer simple and cost-effective method for the preparation of solar cells. The advantages include easy to fabrication, lower cost of the materials and electricity generation under low illumination indoor conditions. DSSCs involve two Transparent Conducting Oxide (TCO) photoelectrodes acting as photoanode and photocathode. In one photoelectrode, Semiconducting oxide $\left(\mathrm{TiO}_{2} / \mathrm{ZnO}\right)$ and dye (Natural/Organometallic) are coated that acts as photo-absorbing materials. The role of dyes and semiconducting material play an important role in determining the photovoltaic conversion efficiency of fabricated solar cells. In this work, hydrothermal method has been adopted for the preparation of pure and silver doped $\mathrm{ZnO}$ nanoparticles using polyethylene glycol (PEG) as capping agent via wet chemical route. The structural and optical properties of the prepared samples were studied using X-ray diffraction (XRD), Fourier Transform Infrared Spectroscopy (FT-IR), Scanning Electron Microscopy (SEM) with Energy Dispersive X-ray Analysis (EDAX) and UV-Visible absorption spectra. A Natural dye from the peels of pomegranate was extracted and dye sensitized solar cells were fabricated with pure and Ag-doped nanoparticles. Both the materials showed the photovoltaic conversion capabilities and showed photoconversion efficiencies. The solar cell fabricated with Ag-doped ZnO semiconducting nanoparticle showed higher short circuit current density as compared to the pure ZnO-nanoparticle synthesized in this study. The photoconversion efficiency of the DSSC based on Ag-doped ZnO showed $30 \%$ more conversion efficiency than the cell without silver doping.

\section{Introduction}

Fossil fuels are widely used in the power generation results in pollution to the environment by emitting toxic gases and causing global warming (Hoffert 2010, Höök \&Tang 2013, Johnsson et al. 2019, Seddon et al. 2021, Wood \&Roelich 2019). Electricity is a primary energy used by mankind and an ever-increasing demand every year. There are numerous efforts for improving the power production and utilization(Kalair et al. 2021, Panwar et al. 2011, Wali et al. 2021). Nuclear power production in a widely used option for the increasing power need due to urbanization(Forsberg 2009, Orhan et al. 2012). After the Fukushima nuclear disaster, the world is in aversion of nuclear power and Germany has already replaced its nuclear reactors with TW solar power(Labib \&Harris 2015, Lochbaum et al. 2014, Mundo-Hernández et al. 2014). Sunlight to electricity conversion is the sustainable and clean energy solution for the future energy needs of the world. P-n-Junction based solar cells are used for the sunlight to electricity conversion and the present solar power production is dominated by the silicon solar cells(Behura et al. 2021, Gong et al. 2019). In spite of monopoly by silicon solar cells, they suffer some disadvantages like, the cost of production and absorption of sunlight in only red light of solar energy(Pizzini 2010, Wenham \&Green 1996). This requires new materials and technologies for the wide absorption of sunlight and without 
increasing the power production cost(Beard et al. 2014, Chalkias et al. 2021, Cunha et al. 2021, Kokkonen et al. 2021, Vlachopoulos et al. 2021).

Dye sensitized solar cells (DSSCs), also known as Grätzel cells offer sunlight to electricity conversion under indoor conditions as compared to the silicon solar cells(Galliano et al. 2021, Grätzel 2003a, 2009, Naim et al. 2021, Parisi et al. 2014, Peter 2011). There are multiple advantages that include simple to fabricate with low-cost materials, multiple wide absorption across the solar energy spectrum as compared to the silicon solar cells. DSSCs include two transparent conducting oxide photoelectrodes bound together and an electrolyte injected between them. DSSCs are fabricated using one FTO coated with a semiconductor $\left(\mathrm{TiO}_{2} / \mathrm{ZnO}\right)$, dye (Natural/Organometallic), and another FTO plate coated with counter electrode (usually, $\mathrm{Pt}$ ) and an electrolyte $\left(\mathrm{I}^{-} / \mathrm{I}_{3}{ }^{-}\right)$injected between them. When light falls on the cell, dye material absorbs sunlight and transfers an electron to the $\mathrm{TiO}_{2}$, which in turn gives away an electron to the electrolyte. The electrolyte acts as the redox shuttle and does two works, by providing an electron to the power output and one electron for the dye regeneration. So, the electron generation and dye regeneration process happens continuously and results in the electricity generation(Campbell et al. 2007, Chen et al. 2009, Freitag et al. 2017, Grätzel 2003b, Patni \&Pillai 2020). Grätzel et al. have first reported the utilization of $\mathrm{TiO}_{2}$ as the semiconducting material with organometallic dye as a sunlight absorber, ${ }^{\top} / I_{3}{ }^{-}$as electrolyte and platinum as the counter electrode(Grätzel 1991, Kohle et al. 1997, O'regan \&Grätzel 1991). During the dye sensitized solar cell fabrication and operation, dye and semiconductor play an important role for obtaining efficient power generation. Dyes including, natural(Ludin et al. 2014, Mary Rosana et al. 2020, Narayan 2012, Shalini et al. 2015), organometallic(Almalki et al. 2021, Chen et al. 2009, Chen et al. 2008, Chen et al. 2006, Joseph et al. 2016, Klein et al. 2005), and organic dyes(Abusaif et al. 2021, Joseph et al. 2019, Mahmood 2016, Mishra et al. 2009, Thomas et al. 2021) were reported for obtaining high power conversion efficiencies among the DSSCs. There are number of metal oxide nanoparticles utilized as the semiconductors for the better performance of DSSCs(Abdelnasser et al. 2020, Jose et al. 2009, Prakash 2012, Sadegh et al. 2021, Vittal \&Ho 2017). Among the semiconductors, $\mathrm{TiO}_{2}$ is commonly used semiconductor that absorbs in the ultraviolet region of the solar energy with the wide band gap of $3.2-3.5 \mathrm{eV}$ (Boro et al. 2018, Hou et al. 2020). At present, the solar cell fabricated with $\mathrm{TiO}_{2}$ and porphyrin dye reached the highest solar power conversion efficiency of 14.5\%(Li \&Diau 2013, Zeng et al. 2020).

Zinc oxide is the wide band gap metal oxide semiconductor that is transparent and absorbs in the ultraviolet visible region of the solar energy(Jaramillo-Páez et al. 2018, Radhika \&Thomas 2017, Rokesh et al. 2018, Vittal \&Ho 2017). It has achieved importance due to its unique features such as high chemical stability, absorption of radiation in a broad range and high photostability. It has potential applications in Optoelectronics, UV light emitters, Laser Technology, Sensors, Energy generation and photocatalysis(Kołodziejczak-Radzimska \&Jesionowski 2014, Vittal \&Ho 2017). Zinc Oxide (ZnO) can also be utilized as the semiconducting material in DSSC and many reports of $\mathrm{ZnO}$ nanoparticles for DSSC fabrication have been reported(Lanjewar \&Gohel 2017). 
In this present study, pure and Ag doped $\mathrm{ZnO}$ nanoparticles were prepared by a facile wet chemical route using polyethylene glycol (PEG) as capping agent. $\mathrm{ZnO}$ and Ag-doped $\mathrm{ZnO}$ were characterized by $\mathrm{X}$-ray diffraction (XRD), Fourier Transform Infrared Spectra (FT-IR), Scanning Electron Microscope (SEM) with Energy Dispersive X-ray Analysis (EDAX) and UV-Visible absorption spectra. These studies revealed the structural and optical properties of the prepared samples. Natural dye from the peels of pomegranate was extracted using ethanol and the purified dye was used as a photosensitizer. The dye sensitized cells were fabricated using the pure and Ag-doped $\mathrm{ZnO}$ nanoparticles, and the pomegranate peel extract. Both the dye and $\mathrm{ZnO}$ nanoparticles showed the photovoltaic properties. Among the fabricated cells, Ag-doped ZnO nanoparticle used dye sensitized cell better conversion efficiency with high current densities as compared to the non-doped cell. The schematic of the solar cell fabricated in this work is shown in Figure 1. Herein, we report the synthesis, characterization and photovoltaic performance of pure and silver doped $\mathrm{ZnO}$ nanoparticles using natural dye obtained from peels of pomegranate.

\section{Materials And Methods}

\subsection{Preparation of Natural Dye from Pomegranate Peels}

Pomegranate peels $(3 \mathrm{~g})$ were washed thoroughly with DD water and air dried. These peels were powdered and soaked in absolute ethanol $(50 \mathrm{~mL})$. This mixture was shaken at regular intervals, and left overnight for dye extraction. The optimum conditions were determined using RSM method. The ethanolic extracts were filtered and concentrated under vacuum using rotavapor. The precipitated materials were filtered out and the dye solutions were filtered through micron filters. The anthocyanin contents were calculated using RSM method. The photoelectrodes were soaked in this dye solutions and dye sensitized cells were assembled for solar cell efficiency measurements.

\subsection{ZnO Nanoparticles Synthesis}

PEG capped ZnO nanoparticles were synthesized as per the following procedure. Zinc acetate $(0.1 \mathrm{M})$ along with PEG $(1 \mathrm{~g})$ was dissolved in double distilled water $(200 \mathrm{~mL})$ and stirred well. Then, sodium hydroxide $(0.2 \mathrm{M})$ dissolved in double distilled water $(200 \mathrm{~mL})$ was added to the above solution drop wise until the $\mathrm{pH}$ of the solution reaches $11-12$. The stirring was continued overnight and the precipitate was filtered, washed thoroughly with water and dried at $100{ }^{\circ} \mathrm{C}$ for $6 \mathrm{~h}$. The dried product was calcined at $500{ }^{\circ} \mathrm{C}$ for $2 \mathrm{~h}$ to obtain the PEG capped $\mathrm{ZnO}$ nanoparticles.

\subsubsection{Ag-doped ZnO Nanoparticle Synthesis}

PEG capped Ag-doped ZnO nanoparticles were synthesized by adding stoichiometric amount of zinc acetate to $1 \%, 2 \%, 3 \%, 4 \%$ and $5 \%$ of silver nitrate with PEG $(1 \mathrm{~g})$ in DD water $(200 \mathrm{~mL})$ and stirred well. Then, sodium hydroxide $(0.2 \mathrm{M})$ was dissolved in DD water $(200 \mathrm{~mL})$ and added to the above solution until the $\mathrm{pH}$ of the solution reaches $11-12$. The stirring was continued overnight, the precipitate was filtered, washed with water and dried at $100{ }^{\circ} \mathrm{C}$ for $6 \mathrm{~h}$. The dried product was calcinated at $500{ }^{\circ} \mathrm{C}$ degrees for $2 \mathrm{~h}$ to obtain the PEG capped Ag-doped ZnO nanoparticles. 


\subsection{Dye Sensitized Solar Cell Fabrication}

The DSSCs were fabricated as per the following procedure. The FTO Glass plates $(2 \times 2 \mathrm{~cm})$ was initially cleaned with ethanol and dried. The conducting side of the glass was identified using a multimeter and this surface was used for the photoelectrode fabrication. The glass plates were stuck with cellophane tape on all four sides and the photoanode was prepared by doctor-blade technique. The prepared zinc oxide powder was mixed with ethanol and converted into a fine paste. The prepared paste was smoothly coated with much care onto the conducting side of the cleaned glass plates using a glass rod. The plates were placed in furnace, heated to a temperature of $420^{\circ} \mathrm{C}$ for a period of $20 \mathrm{~min}$, and cooled further to room temperature. The cooled glass plates were dipped in the pomegranate peel extracted dye solution taken in a small petri dish for overnight at room temperature. The dipped glass plate was tightly covered and used during measurement. The similar procedure was adopted for preparing the photoanodes with silver doped zinc oxide semiconductor. To assemble the cell, a counter electrode is required. To prepare a counter electrode, the procured chloroplatinic acid solution was coated onto the FTO glass plate and sintered at $420^{\circ} \mathrm{C}$ for a period of $15 \mathrm{~min}$. The dye coated electrode was washed gently with ethanol to remove the excess dye present and air dried. Two drops of iodine/iodide electrolyte was gently introduced in between the photoanode and counter electrode to form a complete DSSC device. The fabricated device with the pomegranate dye was subjected to photovoltaic measurement using a solar simulator under conditions of $85 \mathrm{~mW} / \mathrm{cm}^{2}$ and the current density-voltage characteristics were recorded. The same procedure was adopted to fabricate the cells with silver doped semiconductor.

\subsection{Characterization Methods}

The natural dye extracted from the peels of pomegranate was characterized by absorption and FT-IR studies. The synthesized ZnO samples were characterized using Philips PW 3710 X-ray diffractometer and scanning electron microscopy (SEM) JEOL-JSM 6360 with EDAX, respectively. The optical studies were carried out using Perkin Elmer LS-35 Spectrometer. FT-IR spectra were recorded using the thin pellets (referenced against a $\mathrm{KBr}$ pellet) on a Thermo Licolet is $50 \mathrm{FT}$-IR in the $400-4000 \mathrm{~cm}$ frequency region. The photovoltaic performance of DSSCs were measured using Newport, Oriel Class A, 91195Asolar simulator.

\section{Results And Discussion}

\subsection{Preparation of Natural Dye from Pomegranate Peels}

The natural dye from peels of pomegranate was prepared by powdering the pomegranate peels and extracting the dye using ethanol followed absorption of dyes on the semiconductor surface as shown in Figure 2.

\subsubsection{Optimization of Parameters of the Dye Extraction using RSM}


For effective extraction of dyes, the temperature, time and amount of raw material were optimized using Response Surface Methodology (RSM). Central Composite Design method is selected from which the point where maximum yield could be obtained by varying various parameters. In this model one parameter is kept a constant and the other two are varied from which maximum yield can be obtained.

Table 1. The variable range chosen for the parameters.

\begin{tabular}{|ll|}
\hline Parameters & Range \\
\hline Temperature & $25-45^{\circ} \mathrm{C}$ \\
\hline Time & $30-90$ mins \\
\hline Raw material weight & $0.5-2 \mathrm{~g}$ \\
\hline
\end{tabular}

\subsubsection{RSM graph for variation of time and temperature.}

From the graph shown in Figure 3, the peak value indicated in red shows the highest yield obtained while performing the experimental runs. Here, raw material weight is kept constant and the other parameters are varied simultaneously. We can observe that yield of $38 \%$ had been obtained by placing raw materials weight at $1.25 \mathrm{~g}$ and the rest two i. e. temperature and time were varied. Central composite design method has been used where we get highest peak as well as the lowest peak.

\subsubsection{RSM graph for temperature and time variation.}

As seen in Figure 4, time is kept constant and the other two parameters are varied accordingly based on their range. The graphs are obtained by using the software design expert. The highest yield obtained is $38 \%$

\subsubsection{RSM graph for time and raw material variation.}

Figure 5 shows the variation of time and raw material while temperature was kept constant at $35^{\circ} \mathrm{C}$ while the other two parameters, time and raw materials were varied. We can observe the optimized yield when time is 60 mins and raw material weight is $1.25 \mathrm{~g}$. The optimized yield after performing the runs is $38 \%$.

Table 2. RSM optimization table. 
Std Run Block A: Temperature $\left({ }^{\circ} \mathrm{C}\right)$

B: Time (mins)
C: Raw materials $(\mathrm{g})$
Actual

(\%)

0.5

0.5

0.5

0.5

2

2

2

2

1.25

1.25

1.25

1.25

0.5

2

1.25

1.25

Block 35

1

$17 \quad 11 \quad$ Block 35
60

60

60

60
60

60
1.25
37

8.7

14.1

13.1

10.3

16.7

19.4

21.8

16.3

16.2

16.1

17.6

9.3

8.6

10.5

9.7

17.1

17.7

31.5

29.4

37.2

36.9

35.5

36.9

36.9 


\begin{tabular}{|llllllll}
19 & 8 & $\begin{array}{l}\text { Block } \\
1\end{array}$ & 35 & 60 & 1.25 & 38 & 36.9 \\
\hline 20 & 2 & $\begin{array}{l}\text { Block } \\
1\end{array}$ & 35 & 60 & 1.25 & 36 & 36.9 \\
\hline
\end{tabular}

From Table 2, we can observe that three parameters have been chosen which has to be optimized. Here the predicted vales are based on the software Response Surface Methodology (RSM). The highest yield is obtained at the temperature $=35^{\circ} \mathrm{C}$, time $=60$ mins, raw material weight $=1.25 \mathrm{~g}$, and $38 \%$ dye yield is obtained from experimental runs.

Quantification of anthocyanin present in the dye is also found out using the formula Anthocyanin Content $(\mathrm{mg} / 100 \mathrm{~g})=(\mathrm{A} \times \mathrm{MW} \times \mathrm{DF} \times \mathrm{V} \times 100) /\left(\mathrm{e} \times \mathrm{I} \times \mathrm{m}_{\text {sample }}\right)$ were, A - Absorbance $=0.1628$

MW - Molecular Weight of Anthocyanin $=449.2 \mathrm{~g} / \mathrm{mol}$

DF - Dilution Factor $=1$

V - Solvent Volume $=200 \mathrm{~mL}$

e - molar absorptivity (26900)

I - Cell path Length $(1 \mathrm{~cm})$

$\mathrm{m}$ - dry sample weight $=1.25 \mathrm{~g}$

After substitution of the values,

The anthocyanin content found in pomegranate peel crude dye was found to be $\mathbf{4 3 . 5} \mathbf{m g} / \mathbf{1 0 0 g}$.

\subsection{Characterization of Natural dye from Pomegranate Peels}

\subsubsection{UV-Visible Absorption Spectra}

The absorption spectra of dye extracted from pomegranate peels was recorded in ethanol. The absorption spectrum is characterized by the absorption peaks at $320,400 \mathrm{~nm}$ and a shoulder at $530 \mathrm{~nm}$. All the peaks are characteristics of $\pi-\pi^{\star}$-transitions of the anthocyanin pigment present in the dye(Mary Rosana et al. 2020). The absorption spectrum is shown in the Figure 6. 


\subsubsection{FT-IR Spectra}

The FT-IR spectra of the dye was recorded in mineral oil using Nujol-Mull. The anthocyanins contain aromatic ring, $-\mathrm{C}=\mathrm{O},-\mathrm{C}-\mathrm{O}-\mathrm{C}$ - functional groups. The $-\mathrm{C}-\mathrm{H}$ aromatic stretching frequencies are observed at $3446 \mathrm{~cm}^{-1}$. The $-\mathrm{C}=0$ stretching frequencies are observed at $1637 \mathrm{~cm}^{-1}$. The $-\mathrm{C}-\mathrm{O}-\mathrm{C}-\mathrm{stretching}$ frequency due to ester groups are observed at $1046 \mathrm{~cm}^{-1}$ (Ahliha et al. 2017, Patni et al. 2020). From the absorption and FT-IR spectra we can understand that the anthocyanin groups present in the dye extracted from peels of the pomegranate are mainly responsible for the photovoltaic properties. The functional groups present in the dye can anchor on to $\mathrm{ZnO}$ and efficient electron will be there under sunlight illumination. The FT-IR spectra of the dye is shown in Figure 7.

\subsection{Characterization of $\mathrm{ZnO}$ and Ag-doped ZnO Nanoparticles}

\subsubsection{XRD Analysis}

The XRD pattern of PEG capped (8a) pure and (8b-f) Ag (1-5\%) doped ZnO nanoparticles recorded in the range of $20^{\circ}$ to $80^{\circ}$ and are shown in Figure 8 . All diffraction peaks were for $\mathrm{ZnO}$ with the hexagonal wurtzite structure. The diffraction peaks at $2 \theta$ values are $31.8^{\circ}, 34.6^{\circ}, 36.4^{\circ}, 47.9^{\circ}, 56.9^{\circ}, 63^{\circ}, 66.6^{\circ}, 68.3^{\circ}$, $69.3^{\circ}, 72.5^{\circ}$ and $77.3^{\circ}$ corresponding to (100), (002), (101), (102), (110), (103), (200), (112), (201), (004) and (202), hkl lattice planes, respectively. The data obtained matches with the standard JCPDS file no. 036-1451 (Manikandan et al. 2017). In Figure 8f, two additional weak peaks were obtained at $38.2^{\circ}$ and $44.4^{\circ}$ corresponds to (111) and (200) lattice planes of face centered cubic ( $\left.f c c\right)$ structure of Ag. This matches with the standard JCPDS file no. 4-0783 (Zheng et al. 2007).

\subsubsection{FT-IR Spectra}

FT-IR spectra of (9a) PEG (9b) PEG capped pure and (9c) Ag (3\%) doped ZnO nanoparticles were recorded in the range $400-4000 \mathrm{~cm}^{-1}$ and are shown in Figure 9 . Various functional groups and metal-oxide bonds present in the compound were analyzed using FT-IR analysis. In the FT-IR spectra, a significant peak at $432 \mathrm{~cm}^{-1}$ is attributed to the $\mathrm{ZnO}$ stretching mode (Babu et al. 2014, Parvin et al. 2012). The peak at 923 $\mathrm{cm}^{-1}$ indicates the aromatic $\mathrm{C}=\mathrm{C}$ stretching mode (Gayen et al. 2011). The Absorption band at $3422 \mathrm{~cm}^{-1}$ attributes to the $\mathrm{O}-\mathrm{H}$ group stretching mode, which indicates the existence of a small quantities of water absorbed by the $\mathrm{ZnO}$ nanostructure (Nakamoto 2006). The peak at $2347 \mathrm{~cm}^{-1}$ is due to the atmospheric $\mathrm{CO}_{2}$. The peaks at $1391 \mathrm{~cm}^{-1}$ and $1535 \mathrm{~cm}^{-1}$ depicts the stretching modes of $\mathrm{C}-0$ and $\mathrm{C}=0$ groups. Stronger and wider absorption bands are observed in the region $1128-830 \mathrm{~cm}^{-1}$ due to doping. All these observations reveal the formation of PEG capped silver doped $\mathrm{ZnO}$ nanoparticles.

\subsubsection{UV-Visible Spectral Analysis}

Absorption spectra of the PEG capped pure and Silver (1-5\%) doped ZnO samples were measured by UVVisible spectra (Pal \&Giri 2010). Figure 10 shows the UV-Visible spectra of PEG capped pure and Silver (15\%) doped ZnO nanoparticles. PEG capped pure ZnO nanoparticles showed strong UV absorption around 
$382 \mathrm{~nm}$ that could be related to the wurtzite crystal structure of $\mathrm{ZnO}$ (Wahab et al. 2007). PEG capped Ag doped $\mathrm{ZnO}$ nanoparticles exhibit the absorption band towards higher wavelength. Changes in the absorption peak due to doping exhibited changes in the band structure. The absorption band shift represents the change in the optical energy gap (Mittal et al. 2014).

\subsubsection{SEM and EDAX Analysis}

The surface morphological study and elemental composition of the prepared samples was performed using scanning electron micrographs (SEM) and energy dispersive X-ray analysis (EDAX). Figure 11 (a-c) shows the SEM and EDAX pattern of pure ZnO nanoparticles. From the SEM images, Figure 11a and 11b, the $\mathrm{ZnO}$ nanoparticles were formed with spherical shape and without agglomeration. PEG ensures the formation of well separated spherical shaped nanoparticles. Figure 11c shows the EDAX of ZnO nanoparticles. It indicates the percentage of zinc as $70 \%$ and oxygen percentage as $18 \%$ that confirms the formation of $\mathrm{ZnO}$ nanoparticles.

Figure $12 \mathrm{a}$ and $12 \mathrm{~b}$ shows the SEM images of Ag-doped ZnO nanoparticles. Due to the silver doping the spherical shape of $\mathrm{ZnO}$ nanoparticles changed to oval shape as observed in the SEM images. PEG capping ensures the formation of well separated oval-shaped nanoparticles. Figure 12c shows the EDAX of silver doped $\mathrm{ZnO}$ nanoparticles. The percentage of zinc was found to be $58 \%$, and oxygen percentage was found to be $12 \%$ and silver percentage was $2.7 \%$. The SEM images and EDAX indicates the formation of oval shaped Ag-doped ZnO nanoparticles.

\subsection{Photovoltaic Performance}

The current-voltage characteristics of the fabricated DSSCs were measured at 1 sun radiation and are shown in Figure 13. The photovoltaic parameters are listed in Table 3. The DSSC cell with ZnO semiconductor shows the current density, $J_{\mathrm{SC}}=5.6 \mathrm{~mA} / \mathrm{cm}^{2}$, output voltage, $V_{\mathrm{OC}}=0.71 \mathrm{~V}$, fill factor, $f f=$ 0.46 and the power conversion efficiency, $\eta=1.8 \%$. The $J_{\mathrm{SC}}, V_{\mathrm{OC}}$, ff and efficiency values can be compared with that of the previously reported in the literature work. The anthocyanin from pomegranate leaves and ZnO fabricated DSSC have shown the $J_{S C}=1.89 \mathrm{~mA} / \mathrm{cm}^{2}, V_{\mathrm{OC}}=0.555 \mathrm{~V}, f f=0.49 \%$ and $\eta=$ 0.548\% (Chang \&Lo 2010). The DSSC fabricated with pomegranate juice and ZnO semiconductor have shown the $J_{\mathrm{SC}}=5.1 \mathrm{~mA} / \mathrm{cm}^{2}, V_{\mathrm{OC}}=0.312 \mathrm{~V}, f f=0.272 \%$ and $\eta=0.43 \%$ (Sirimanne et al. 2006), and with $\mathrm{TiO}_{2}$ semiconductor have shown the $J_{\mathrm{SC}}=2.2 \mathrm{~mA} / \mathrm{cm}^{2}, V_{\mathrm{OC}}=0.370 \mathrm{~V}, \mathrm{ff}=0.45 \%$ and $\eta=0.36 \%$ (Bazargan et al. 2011). The DSSC fabricated with silver-doped $\mathrm{ZnO}$ semiconductor shows the current density, $J_{\mathrm{SC}}=0.68 \mathrm{~mA} / \mathrm{cm}^{2}$, output voltage, $V_{\mathrm{OC}}=7.9 \mathrm{~V}$, fill factor, $f f=0.39$ and the power conversion efficiency, $\eta=2.1 \%$.

The performance of ZnO based DSSCs are higher than the DSSCs reported in the literature. The dye purification followed optimization of maximum dye extraction and utilization for the DSSC fabrication enhances the DSSC performance. The lack of aggregation and the formation of spherical nanoparticles as inferred from the HR-SEM data can also contribute to the enhanced DSSC performance. From the 
photovoltaic data, we can observe that there is $30 \%$ increase in the power conversion efficiency of DSSC based on Ag-doped $\mathrm{ZnO}$ semiconductor. The increase in the photovoltaic performance of Ag-doped ZnO is due to the powerful electron injection facilitated by the Ag-ion present in the $\mathrm{ZnO}$ semiconductor. The oval-shaped Ag-doped $\mathrm{ZnO}$ without the aggregation as seen from the SEM data can also contribute to the efficiency of DSSC.

Table 3. Photovoltaic Performance of DSSCs.

\begin{tabular}{|c|c|c|c|c|c|}
\hline Dye & $\begin{array}{l}J_{S C} \\
\left(m A / c^{2}\right)\end{array}$ & $\begin{array}{l}v_{\mathrm{oc}} \\
(V)\end{array}$ & $\begin{array}{l}f f \\
(\%)\end{array}$ & $\begin{array}{l}\eta \\
\text { (\%) }\end{array}$ & Reference \\
\hline Pome. Leaves -Anthocyanin & 1.89 & 0.555 & 0.49 & 0.548 & (Chang \&Lo 2010) \\
\hline Pomegranate Dye + Zno & 5.1 & 0.312 & 0.27 & 0.43 & (Sirimanne et al. 2006) \\
\hline Pomegranate Dye + Zno & 2.52 & 0.63 & 0.61 & 0.97 & (Chauhan et al. 2016) \\
\hline Pomegranate Dye $+\mathrm{TiO}_{2}$ & 2.2 & 0.370 & 0.45 & 0.366 & (Bazargan et al. 2011) \\
\hline Pure ZnO + Pome. Dye & 5.6 & 0.71 & 0.46 & 1.8 & Present Work \\
\hline Ag-Doped ZnO + Pome. Dye & 7.9 & 0.68 & 0.39 & 2.1 & Present Work \\
\hline
\end{tabular}

\section{Conclusions}

In summary, we have described a simple and cost-effective method for the conversion of natural waste from pomegranate peels into electricity. The natural dye from pomegranate peels was extracted by grinding the peels into powder and extracting with ethanol. The natural dye extracts were characterized by UV-Visible and FT-IR spectra. ZnO and Ag doped ZnO nanoparticles were synthesized by a facile hydrothermal method. The particle shape and size of $\mathrm{ZnO}$ and Ag-doped $\mathrm{ZnO}$ were controlled by using polyethylene glycol (PEG) as the capping agent. The structural and optical properties of prepared samples were studied using XRD, FT-IR, SEM-EDAX and UV-Visible analysis. The SEM analysis of ZnO nanoparticles showed the formation of spherical shaped nanoparticles without agglomeration. The EDAX analysis of $\mathrm{ZnO}$ nanoparticles indicated the formation of $\mathrm{ZnO}$ nanoparticles with $70 \%$ of zinc and $18 \%$ of oxygen. The SEM images of Ag-doped ZnO indicated the formation of oval-shaped nanoparticles due to Ag-doping. The EDAX analysis indicated the formation of Ag-doped $\mathrm{ZnO}$ with $58 \%$ of zinc, $18 \%$ of oxygen and $2.7 \%$ of silver. The DSSC cell with ZnO semiconductor showed the current density, $J_{S C}=0.71$ $\mathrm{mA} / \mathrm{cm}^{2}$, output voltage, $V_{\mathrm{OC}}=5.6 \mathrm{~V}$, fill factor, $f f=0.46$ and the power conversion efficiency, $\eta=1.8 \%$. The DSSC fabricated with silver-doped ZnO semiconductor showed the current density, $J_{S C}=0.68$ $\mathrm{mA} / \mathrm{cm}^{2}$, output voltage, $V_{\mathrm{OC}}=7.9 \mathrm{~V}$, fill factor, $f f=0.39$ and the power conversion efficiency, $\eta=2.1 \%$. The performance of DSSCs is higher than the DSSC performance of the similar pomegranate based solar cells. From the photovoltaic data, we can observe that there is $30 \%$ increase in the power conversion efficiency of DSSC based on Ag-doped ZnO semiconductor. The increase in the photovoltaic performance 
of Ag-doped $\mathrm{ZnO}$ is due to the powerful electron injection facilitated by the Ag-ion doped into $\mathrm{ZnO}$ nanoparticle.

In conclusion, the present study offers a simple and cost-effective method for the production of electricity from natural dye obtained from the peels of pomegranate generated everyday as the waste. We believe that the method offers simple, easy to fabrication and cost-effective as clean power production source in societies sustainable development. Also, it reduces the environmental pollution and inspires other researchers to generate power by utilizing more of such natural waste materials. As the energy demand increases every day, the sustainable development can be fulfilled by utilizing renewable energy resources such as sun. The work described in this article utilizes both waste material and renewable source for the generation of electricity.

\section{Declarations}

\section{Conflict of Interest}

Authors declare that there is no conflict of interest related to this work.

\section{Ethical Approval}

Not Applicable. As the work doesn't involve humans/animals.

\section{Consent to Participate}

Not Applicable.

\section{Authors Contributions}

Vincent Joseph Kanniyambatti Lourdusamy designed the work, carried out experiments and written manuscript. Mary Rosana Nalzala Thomas isolated natural dyes. Vijai Anand Kabali synthesized ZnO nanoparticles. Dhilip Kumar Rajaiah helped in the characterization.

\section{Availability of data and materials}

All data generated or analyzed during this study are included in this article

\section{Author Declaration}

The manuscript is written with the contributions of all the authors and all the authors have given approval for the submission of the manuscript.

\section{Source of Support}

Authors declare there is no funding resources for this work.

\section{References}


Abdelnasser S, Al Sakkaf R, Palmisano G (2020): Environmental and energy applications of TiO2 photoanodes modified with alkali metals and polymers. Journal of Environmental Chemical Engineering, 104873

Abusaif MS, Fathy M, Abu-Saied M, Elhenawy AA, Kashyout A, Selim MR, Ammar YA (2021): New carbazole-based organic dyes with different acceptors for dye-sensitized solar cells: Synthesis, characterization, dssc fabrications and density functional theory studies. Journal of Molecular Structure 1225,129297

Ahliha A, Nurosyid F, Supriyanto A, Kusumaningsih T (2017): The chemical bonds effect of anthocyanin and chlorophyll dyes on TiO2 for dye-sensitized solar cell (DSSC), Journal of Physics: Conference Series. IOP Publishing, pp. 012013

Almalki AS, Shoair AGF, Badawi A, Al-Baradi AM, Atta A, Algarni SA, Khalifa ME, Alfaifi SY (2021):

Enhancement of the open-circuit voltage of the dye-sensitized solar cells using a modified ruthenium dye. Applied Physics A 127, 1-8

Babu B, Aswani T, Rao GT, Stella RJ, Jayaraja B, Ravikumar R (2014): Room temperature ferromagnetism and optical properties of $\mathrm{Cu} 2+$ doped $\mathrm{ZnO}$ nanopowder by ultrasound assisted solid state reaction technique. Journal of magnetism and magnetic materials $355,76-80$

Bazargan M, Byranvand MM, Kharat AN, Fatholahi L (2011): Natural pomegranate juice as photosensitizers for dye-sensitized solar cell (DSSC). Journal of Optoelectronics and Advanced MaterialsRapid Communications 5, 360-62

Beard MC, Luther JM, Nozik AJ (2014): The promise and challenge of nanostructured solar cells. Nature nanotechnology 9, 951-954

Behura AK, Kumar A, Rajak DK, Pruncu Cl, Lamberti L (2021): Towards better performances for a novel rooftop solar PV system. Solar Energy 216, 518-529

Boro B, Gogoi B, Rajbongshi B, Ramchiary A (2018): Nano-structured TiO2/ZnO nanocomposite for dyesensitized solar cells application: A review. Renewable and Sustainable Energy Reviews 81, 2264-2270

Campbell WM, Jolley KW, Wagner P, Wagner K, Walsh PJ, Gordon KC, Schmidt-Mende L, Nazeeruddin MK, Wang Q, Grätzel M (2007): Highly efficient porphyrin sensitizers for dye-sensitized solar cells. The Journal of Physical Chemistry C 111, 11760-11762

Chalkias D, Charalampopoulos C, Andreopoulou A, Karavioti A, Stathatos E (2021): Spectral engineering of semi-transparent dye-sensitized solar cells using new triphenylamine-based dyes and an iodine-free electrolyte for greenhouse-oriented applications. Journal of Power Sources 496, 229842

Chang H, Lo Y-J (2010): Pomegranate leaves and mulberry fruit as natural sensitizers for dye-sensitized solar cells. Solar Energy 84, 1833-1837 
Chauhan R, Shinde M, Kumar A, Gosavi S, Amalnerkar DP (2016): Hierarchical zinc oxide pomegranate and hollow sphere structures as efficient photoanodes for dye-sensitized solar cells. Microporous and Mesoporous Materials 226, 201-208

Chen C-Y, Wang M, Li J-Y, Pootrakulchote N, Alibabaei L, Ngoc-le C-h, Decoppet J-D, Tsai J-H, Grätzel C, Wu C-G (2009): Highly efficient light-harvesting ruthenium sensitizer for thin-film dye-sensitized solar cells. ACS nano 3, 3103-3109

Chen CY, Wu SJ, Wu CG, Chen JG, Ho KC (2006): A Ruthenium complex with superhigh light-harvesting capacity for dye-sensitized solar cells. Angewandte chemie 118, 5954-5957

Chen CY, Chen JG, Wu SJ, Li JY, Wu CG, Ho KC (2008): Multifunctionalized ruthenium-based supersensitizers for highly efficient dye-sensitized solar cells. Angewandte Chemie 120, 7452-7455

Cunha JM, Oliveira K, Lontchi J, Lopes TS, Curado MA, Barbosa JR, Vinhais C, Chen W-C, Borme J, Fonseca H (2021): High-Performance and Industrially Viable Nanostructured SiOx Layers for Interface Passivation in Thin Film Solar Cells. Solar RRL 5, 2000534

Forsberg CW (2009): Sustainability by combining nuclear, fossil, and renewable energy sources. Progress in Nuclear energy $51,192-200$

Freitag M, Teuscher J, Saygili Y, Zhang X, Giordano F, Liska P, Hua J, Zakeeruddin SM, Moser J-E, Grätzel $M$ (2017): Dye-sensitized solar cells for efficient power generation under ambient lighting. Nature Photonics 11, 372-378

Galliano S, Bella F, Bonomo M, Giordano F, Grätzel M, Viscardi G, Hagfeldt A, Gerbaldi C, Barolo C (2021): Xanthan-Based Hydrogel for Stable and Efficient Quasi-Solid Truly Aqueous Dye-Sensitized Solar Cell with Cobalt Mediator. Solar Rrl, 2000823

Gayen R, Sarkar K, Hussain S, Bhar R, Pal A (2011): ZnO films prepared by modified sol-gel technique.

Gong J, Li C, Wasielewski MR (2019): Advances in solar energy conversion. Chemical Society Reviews 48, 1862-1864

Grätzel M (1991): The artificial leaf, molecular photovoltaics achieve efficient generation of electricity from sunlight. Comments on Inorganic Chemistry 12, 93-111

Grätzel M (2003a): Dye-sensitized solar cells. Journal of photochemistry and photobiology C: Photochemistry Reviews 4, 145-153

Grätzel M (2003b): Solar cells to dye for. Nature 421, 586-587

Grätzel M (2009): Recent advances in sensitized mesoscopic solar cells. Accounts of chemical research $42,1788-1798$ 
Hoffert MI (2010): Farewell to fossil fuels? Science 329, 1292-1294

Höök M, Tang X (2013): Depletion of fossil fuels and anthropogenic climate change-A review. Energy policy $52,797-809$

Hou X, Aitola K, Lund PD (2020): TiO2 nanotubes for dye-sensitized solar cells-A review. Energy Science \& Engineering

Jaramillo-Páez C, Sánchez-Cid P, Navío JA, Hidalgo M (2018): A comparative assessment of the UVphotocatalytic activities of $\mathrm{ZnO}$ synthesized by different routes. Journal of environmental chemical engineering $6,7161-7171$

Johnsson F, Kjärstad J, Rootzén J (2019): The threat to climate change mitigation posed by the abundance of fossil fuels. Climate Policy 19, 258-274

Jose R, Thavasi V, Ramakrishna S (2009): Metal oxides for dye-sensitized solar cells. Journal of the American Ceramic Society 92, 289-301

Joseph KLV, Anthonysamy A, Easwaramoorthi R, Shinde DV, Ganapathy V, Karthikeyan S, Lee J, Park T, Rhee S-W, Kim KS (2016): Cyanoacetic acid tethered thiophene for well-matched LUMO level in Ru (II)terpyridine dye sensitized solar cells. Dyes and Pigments 126, 270-278

Joseph KV, Rosana NM, Easwaramoorthi R, Vijaya JJ, Karthikeyan S, Kim J (2019): Output current enhancement of hexylthiophene functionalized $D-\pi$-extended-A triphenylamine in dye sensitized solar cells. New Journal of Chemistry 43, 10834-10840

Kalair A, Abas N, Saleem MS, Kalair AR, Khan N (2021): Role of energy storage systems in energy transition from fossil fuels to renewables. Energy Storage 3, e135

Klein C, Nazeeruddin MK, Liska P, Di Censo D, Hirata N, Palomares E, Durrant J, Grätzel M (2005): Engineering of a novel ruthenium sensitizer and its application in dye-sensitized solar cells for conversion of sunlight into electricity. Inorganic Chemistry 44, 178-180

Kohle O, Grätzel M, Meyer AF, Meyer TB (1997): The photovoltaic stability of, bis (isothiocyanato) rlutheniurn (II)-bis-2, 2' bipyridine-4, 4'-dicarboxylic acid and related sensitizers. Advanced Materials 9, 904-906

Kokkonen M, Talebi P, Zhou J, Asgari S, Soomro SA, Elsehrawy F, Halme J, Ahmad S, Hagfeldt A, Hashmi SG (2021): Advanced research trends in dye-sensitized solar cells. Journal of Materials Chemistry A

Kołodziejczak-Radzimska A, Jesionowski T (2014): Zinc oxide-from synthesis to application: a review. Materials 7, 2833-2881 
Labib A, Harris M (2015): Learning how to learn from failures: The Fukushima nuclear disaster. Engineering Failure Analysis 47, 117-128

Lanjewar M, Gohel JV (2017): Enhanced performance of Ag-doped ZnO and pure ZnO thin films DSSCs prepared by sol-gel spin coating. Inorganic and Nano-Metal Chemistry 47, 1090-1096

Li L-L, Diau EW-G (2013): Porphyrin-sensitized solar cells. Chemical society reviews 42, 291-304

Lochbaum D, Lyman E, Stranahan SQ (2014): Fukushima: The story of a nuclear disaster. New Press, The Ludin NA, Mahmoud AA-A, Mohamad AB, Kadhum AAH, Sopian K, Karim NSA (2014): Review on the development of natural dye photosensitizer for dye-sensitized solar cells. Renewable and Sustainable Energy Reviews 31, 386-396

Mahmood A (2016): Triphenylamine based dyes for dye sensitized solar cells: A review. Solar energy 123, $127-144$

Manikandan H, Ahmed M, Ganesan V (2017): Enhanced bioactivity of Ag/ZnO Nanorods-A comparative antibacterial study (Sbds). J. Nanomed. Nanotechnol. 4, 1-7

Mary Rosana NT, Joshua Amarnath D, Senthil Kumar P, Vincent Joseph KL (2020): Potential of plantbased photosensitizers in dye-sensitized solar cell applications. Environmental Progress \& Sustainable Energy 39, e13351

Mishra A, Fischer MK, Bäuerle P (2009): Metal-free organic dyes for dye-sensitized solar cells: From structure: Property relationships to design rules. Angewandte Chemie International Edition 48, 2474-2499

Mittal M, Sharma M, Pandey O (2014): UV-Visible light induced photocatalytic studies of Cu doped ZnO nanoparticles prepared by co-precipitation method. Solar Energy 110, 386-397

Mundo-Hernández J, de Celis Alonso B, Hernández-Álvarez J, de Celis-Carrillo B (2014): An overview of solar photovoltaic energy in Mexico and Germany. Renewable and Sustainable Energy Reviews 31, 639649

Naim W, Novelli V, Nikolinakos I, Barbero N, Dzeba I, Grifoni F, Ren Y, Alnasser T, Velardo A, Borrelli R (2021): Transparent and Colorless Dye-Sensitized Solar Cells Exceeding 75\% Average Visible Transmittance. JACS Au

Nakamoto K (2006): Infrared and R aman spectra of inorganic and coordination compounds. Handbook of vibrational spectroscopy

Narayan MR (2012): Dye sensitized solar cells based on natural photosensitizers. Renewable and Sustainable Energy Reviews 16, 208-215 
O'regan B, Grätzel M (1991): A low-cost, high-efficiency solar cell based on dye-sensitized colloidal TiO 2 films. nature $353,737-740$

Orhan MF, Dincer I, Rosen MA, Kanoglu M (2012): Integrated hydrogen production options based on renewable and nuclear energy sources. Renewable and Sustainable Energy Reviews 16, 6059-6082

Pal B, Giri P (2010): High temperature ferromagnetism and optical properties of Co doped ZnO nanoparticles. Journal of applied physics 108,084322

Panwar N, Kaushik S, Kothari S (2011): Role of renewable energy sources in environmental protection: A review. Renewable and sustainable energy reviews 15, 1513-1524

Parisi ML, Maranghi S, Basosi R (2014): The evolution of the dye sensitized solar cells from Grätzel prototype to up-scaled solar applications: A life cycle assessment approach. Renewable and Sustainable Energy Reviews 39, 124-138

Parvin T, Keerthiraj N, Ibrahim IA, Phanichphant S, Byrappa K (2012): Photocatalytic degradation of municipal wastewater and brilliant blue dye using hydrothermally synthesized surface-modified silverdoped ZnO designer particles. International Journal of Photoenergy 2012

Patni N, G. Pillai S, Sharma P (2020): Effect of using betalain, anthocyanin and chlorophyll dyes together as a sensitizer on enhancing the efficiency of dye-sensitized solar cell. International Journal of Energy Research 44, 10846-10859

Patni N, Pillai SG (2020): Optimization of the doping of polyaniline via response surface method to prepare polymer electrolytes for dye sensitized solar cells. Journal of Environmental Chemical Engineering 8, 103709

Peter LM (2011): The gratzel cell: where next? The Journal of Physical Chemistry Letters 2, 1861-1867 Pizzini S (2010): Towards solar grade silicon: Challenges and benefits for low cost photovoltaics. Solar energy materials and solar cells $94,1528-1533$

Prakash T (2012): Review on nanostructured semiconductors for dye sensitized solar cells. Electronic materials letters 8, 231-243

Radhika S, Thomas J (2017): Solar light driven photocatalytic degradation of organic pollutants using $\mathrm{ZnO}$ nanorods coupled with photosensitive molecules. Journal of environmental chemical engineering 5 , 4239-4250

Rokesh K, Mohan SC, Karuppuchamy S, Jothivenkatachalam K (2018): Photo-assisted advanced oxidation processes for Rhodamine $\mathrm{B}$ degradation using $\mathrm{ZnO}-\mathrm{Ag}$ nanocomposite materials. Journal of environmental chemical engineering $6,3610-3620$ 
Sadegh F, Modarresi-Alam AR, Noroozifar M, Kerman K (2021): A facile and green synthesis of superparamagnetic Fe304@ PANI nanocomposite with a core-shell structure to increase of triplet state population and efficiency of the solar cells. Journal of Environmental Chemical Engineering 9, 104942

Seddon N, Smith A, Smith P, Key I, Chausson A, Girardin C, House J, Srivastava S, Turner B (2021): Getting the message right on nature-based solutions to climate change. Global Change Biology 27, 1518-1546

Shalini S, Prasanna S, Mallick TK, Senthilarasu S (2015): Review on natural dye sensitized solar cells: operation, materials and methods. Renewable and Sustainable Energy Reviews 51, 1306-1325

Sirimanne PM, Senevirathna M, Premalal E, Pitigala P, Sivakumar V, Tennakone K (2006): Utilization of natural pigment extracted from pomegranate fruits as sensitizer in solid-state solar cells. Journal of Photochemistry and Photobiology A: Chemistry 177, 324-327

Thomas MRN, Lourdusamy VJK, Dhandayuthapani AA, Jayakumar V (2021): Non-metallic organic dyes as photosensitizers for dye-sensitized solar cells: a review. Environmental Science and Pollution Research, 1-15

Vittal R, Ho K-C (2017): Zinc oxide based dye-sensitized solar cells: A review. Renewable and Sustainable energy reviews $70,920-935$

Vlachopoulos N, Hagfeldt A, Benesperi I, Freitag M, Hashmi G, Jia G, Wahyuono RA, Plentz J, Dietzek B (2021): New approaches in component design for dye-sensitized solar cells. Sustainable Energy \& Fuels $5,367-383$

Wahab R, Ansari S, Kim Y, Seo H, Kim G, Khang G, Shin H-S (2007): Low temperature solution synthesis and characterization of ZnO nano-flowers. Materials Research Bulletin 42, 1640-1648

Wali SB, Hannan M, Reza M, Ker PJ, Begum R, Abd Rahman M, Mansor M (2021): Battery storage systems integrated renewable energy sources: A biblio metric analysis towards future directions. Journal of Energy Storage 35, 102296

Wenham SR, Green MA (1996): Silicon solar cells. Progress in Photovoltaics: Research and Applications 4, 3-33

Wood N, Roelich K (2019): Tensions, capabilities, and justice in climate change mitigation of fossil fuels. Energy Research \& Social Science 52, 114-122

Zeng K, Tong Z, Ma L, Zhu W-H, Wu W, Xie Y (2020): Molecular engineering strategies for fabricating efficient porphyrin-based dye-sensitized solar cells. Energy \& Environmental Science 13, 1617-1657

Zheng Y, Zheng L, Zhan Y, Lin X, Zheng Q, Wei K (2007): Ag/ZnO heterostructure nanocrystals: synthesis, characterization, and photocatalysis. Inorganic chemistry 46, 6980-6986. 
Figures

\section{Sunlight}

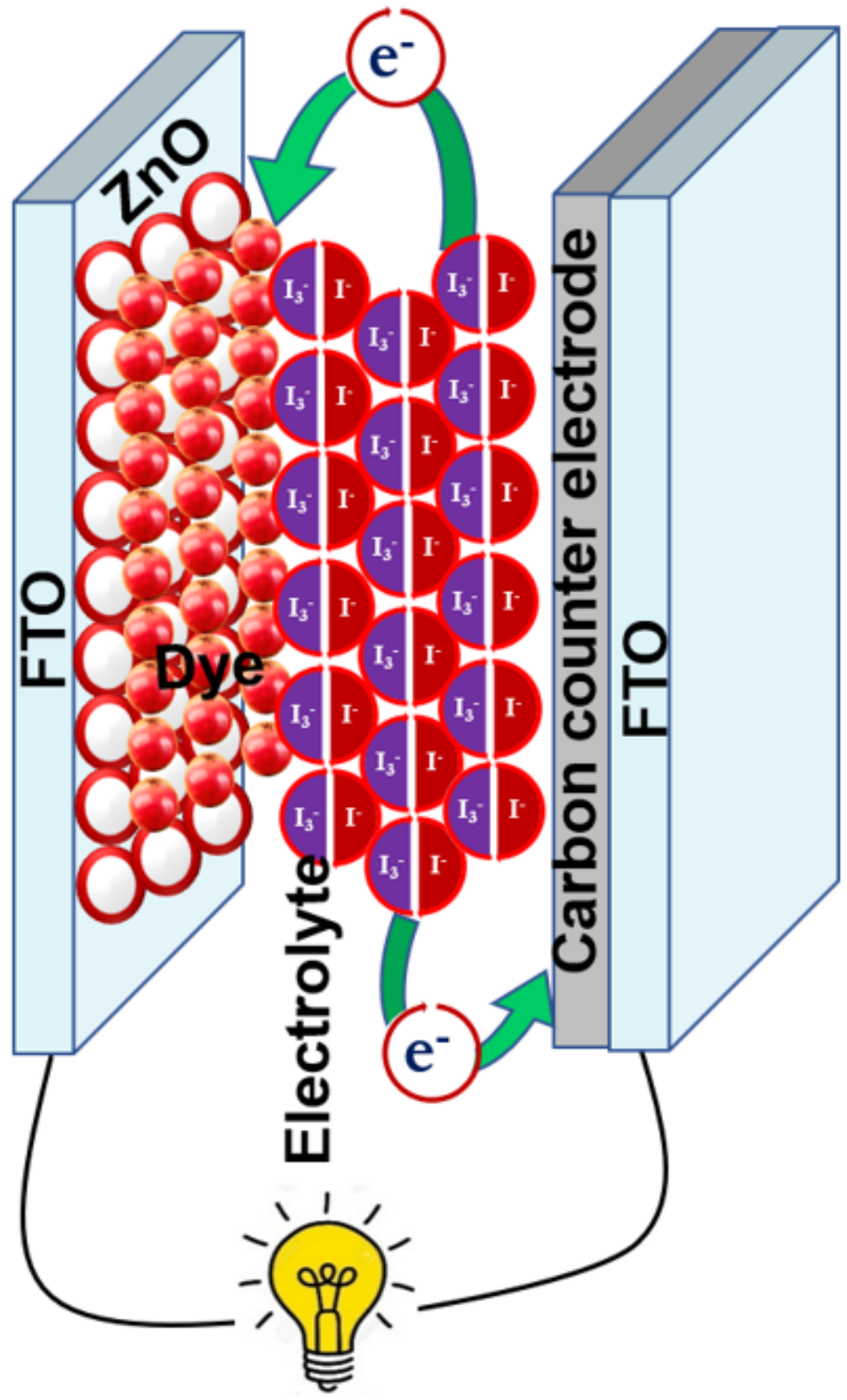

Figure 1

Schematic of natural waste to electricity conversion system. 


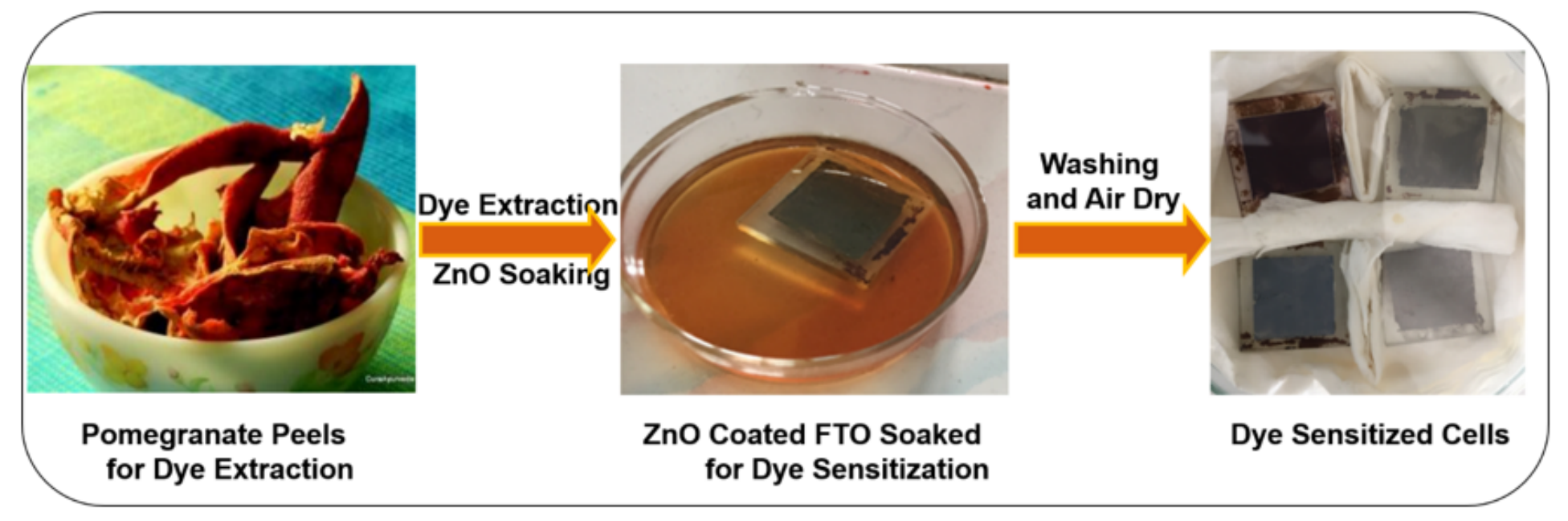

Figure 2

Scheme for the dye extraction and photoelectrode assembly.

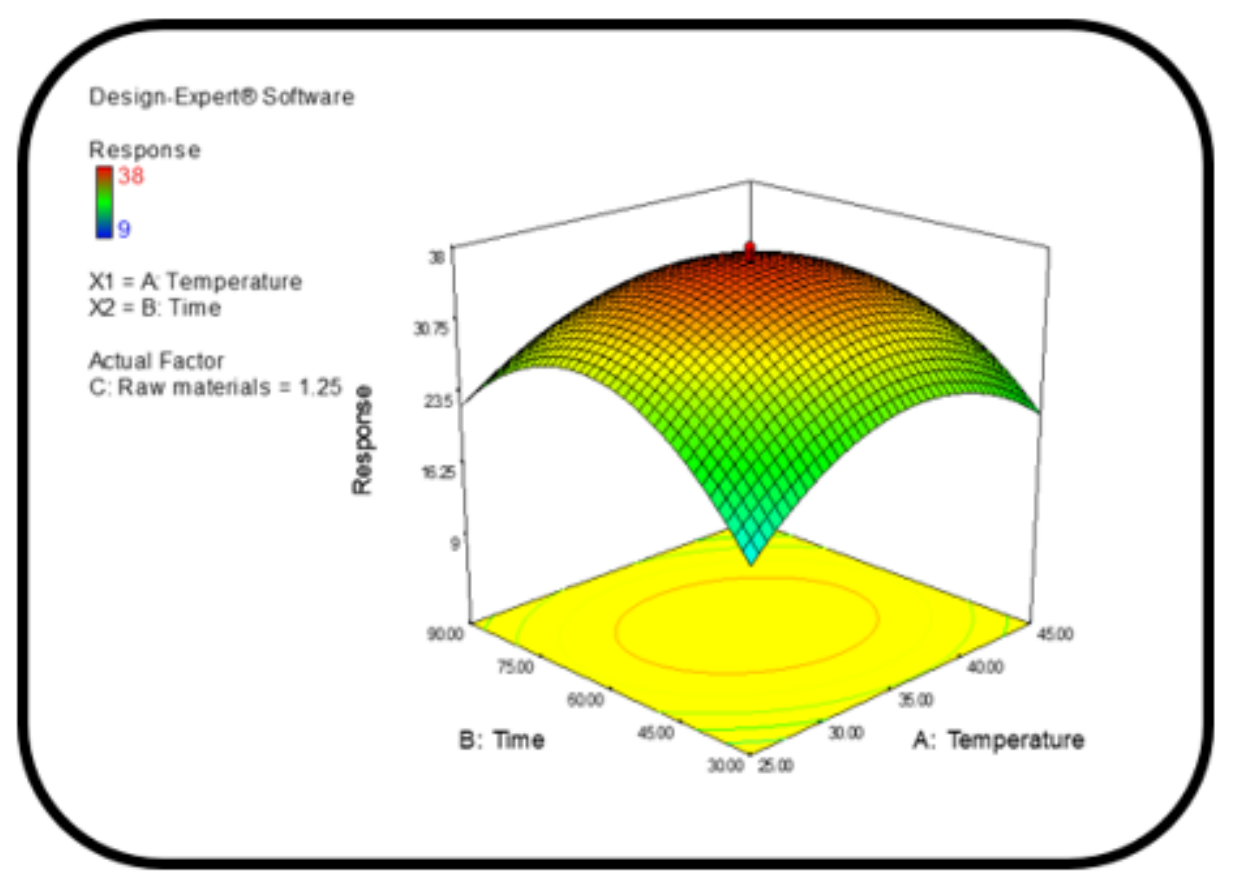

Figure 3

RSM graph for variation of time and temperature. 
Design-Experto Software

Response

$\prod_{9}^{38}$

$\mathrm{X}_{1}=\mathrm{A} \cdot \mathrm{T}$ Temperature

$\mathrm{X}=\mathrm{C}$ : Raw materials

Actual Factor

B: Time $=60.00$

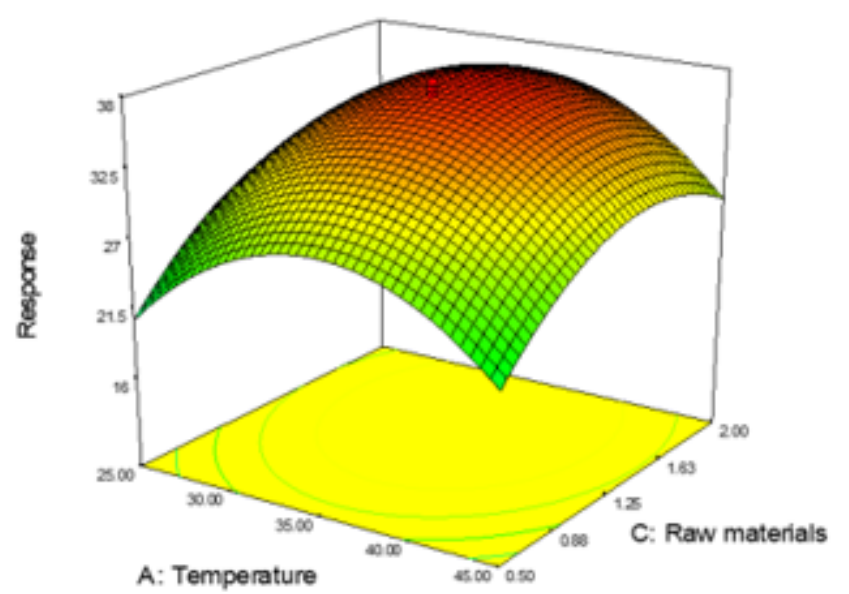

Figure 4

RSM graph for temperature and time variation.

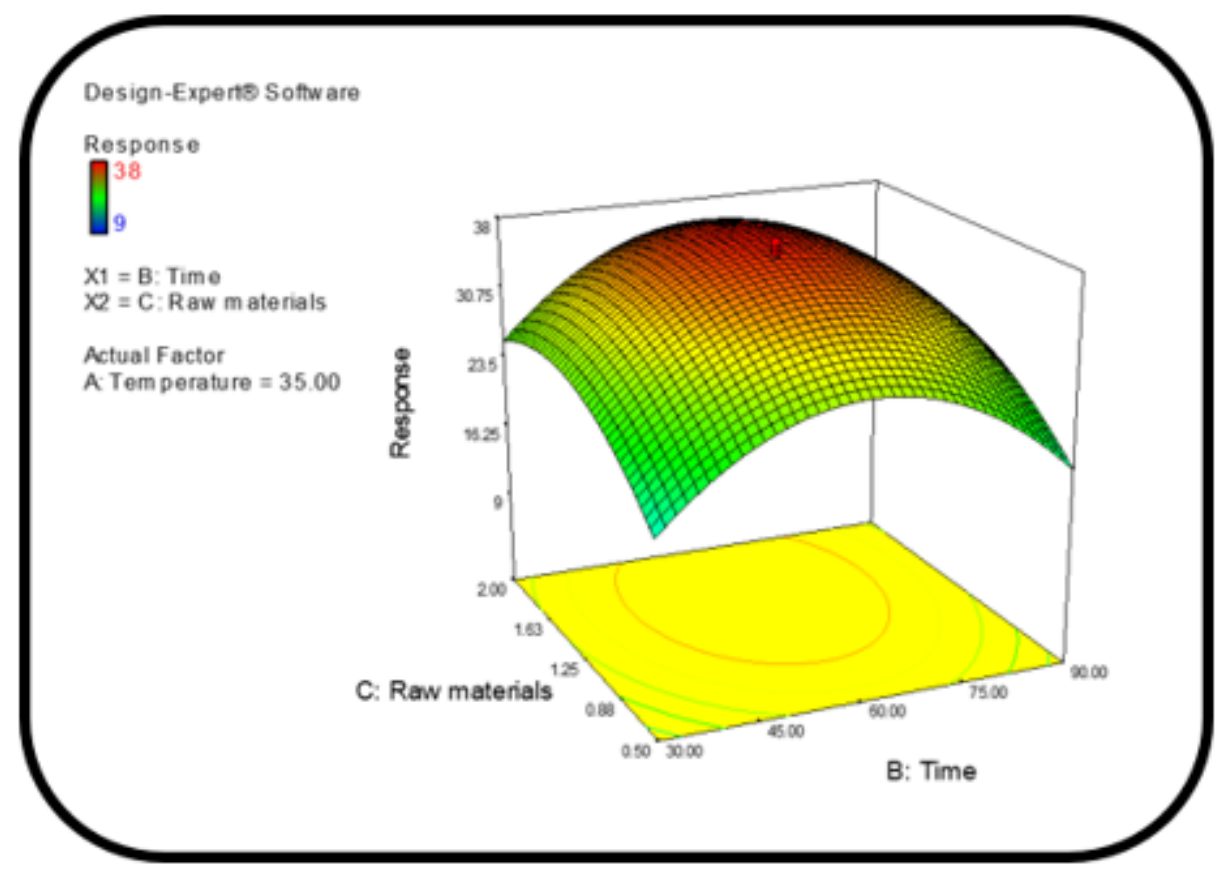

Figure 5

RSM graph for time and raw material variation. 


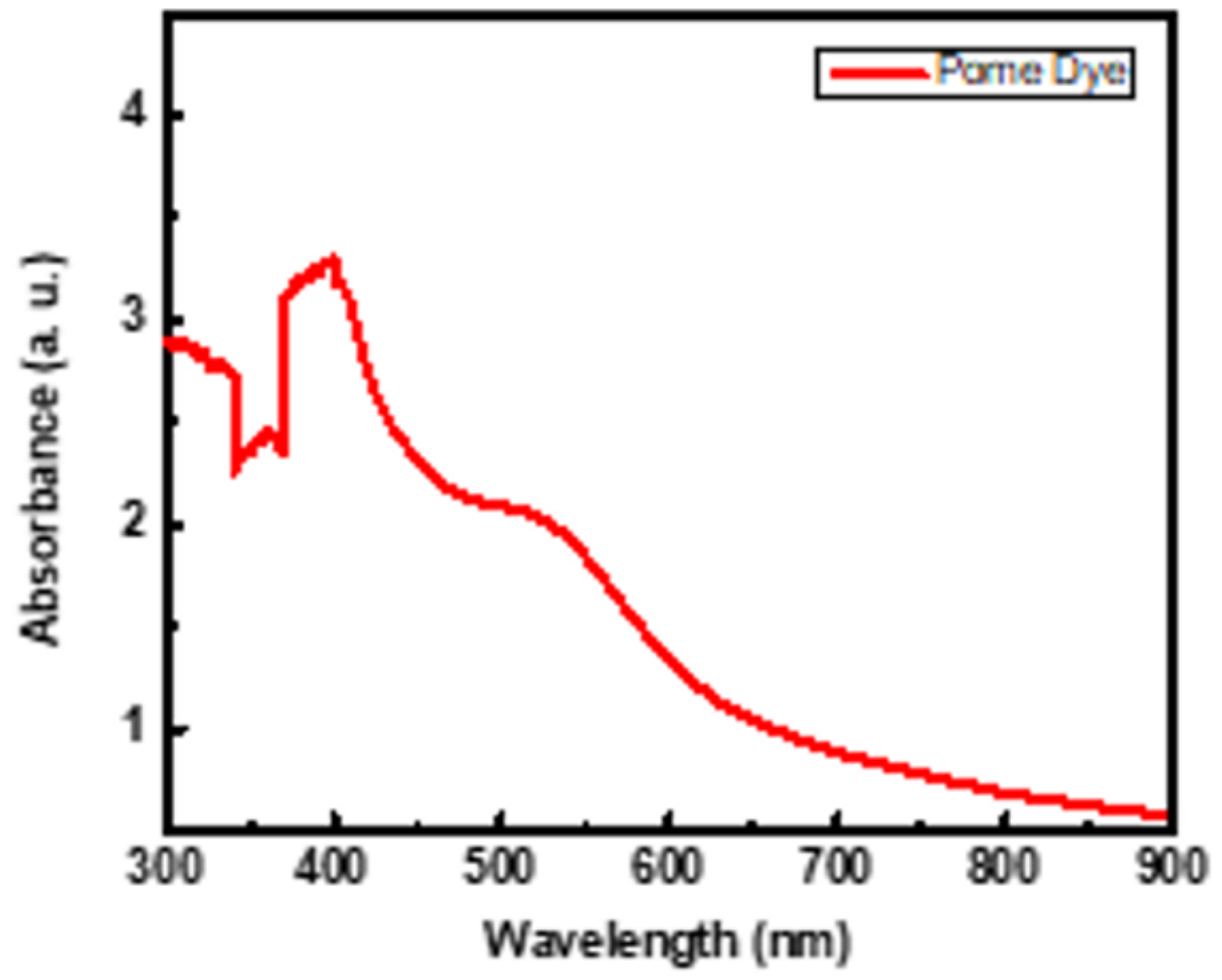

Figure 6

Absorption spectra of the dye extracted from peels of pomegranate 


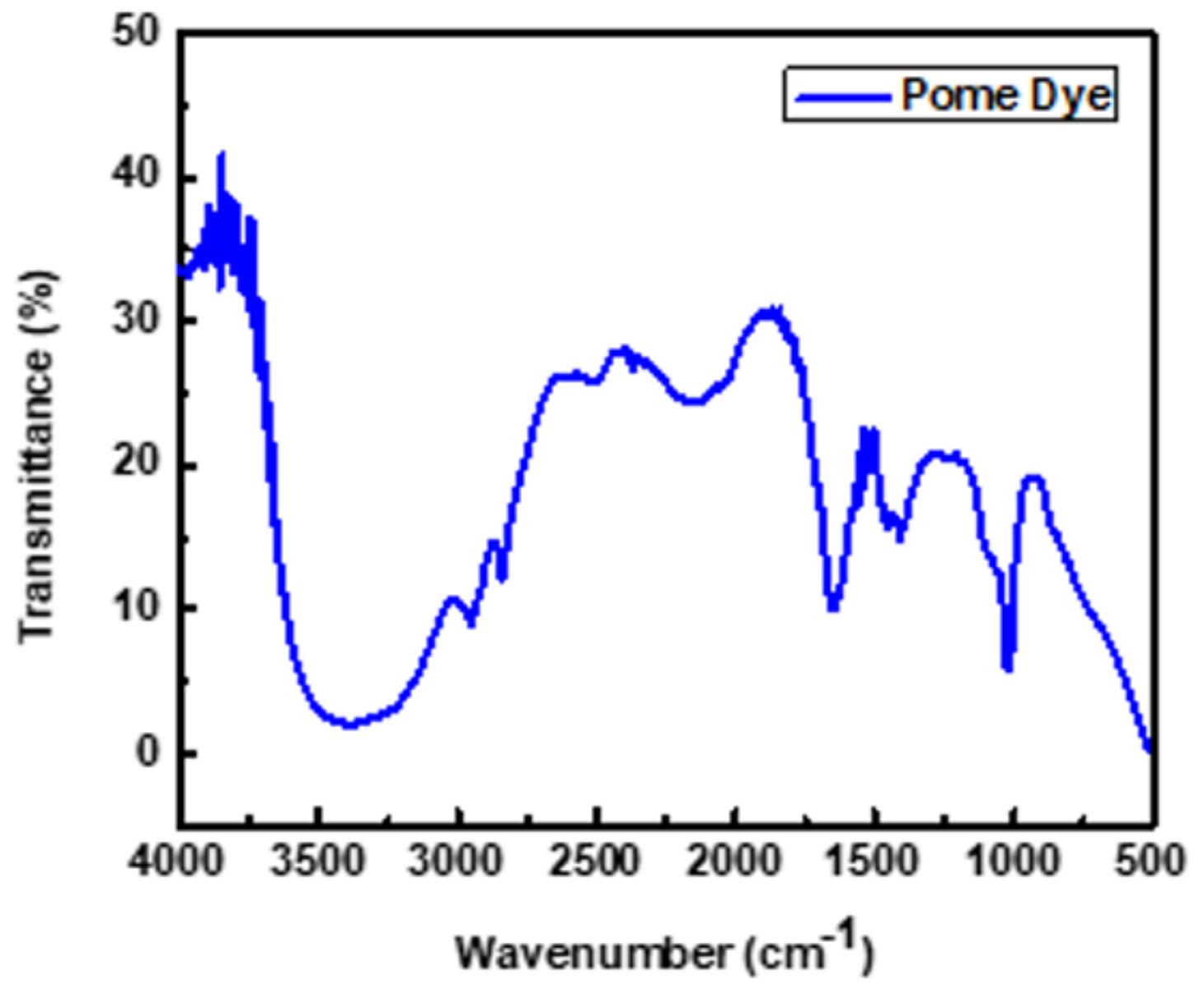

Figure 7

FTIR spectra of the dye extracted from peels of pomegranate 


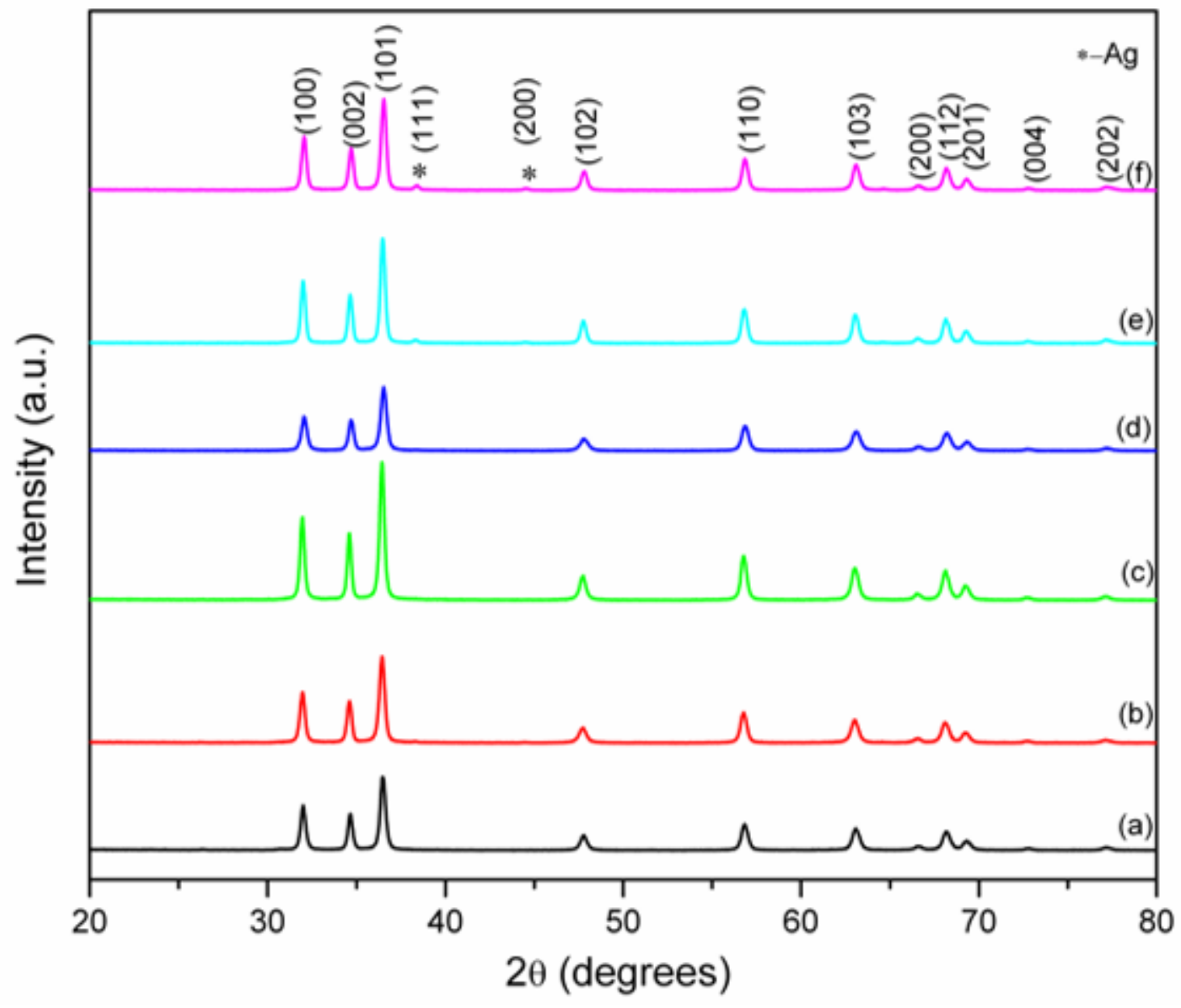

Figure 8

XRD of PEG capped (a) pure ZnO and (b-f) Ag (1-5 \%) doped ZnO nanoparticles 


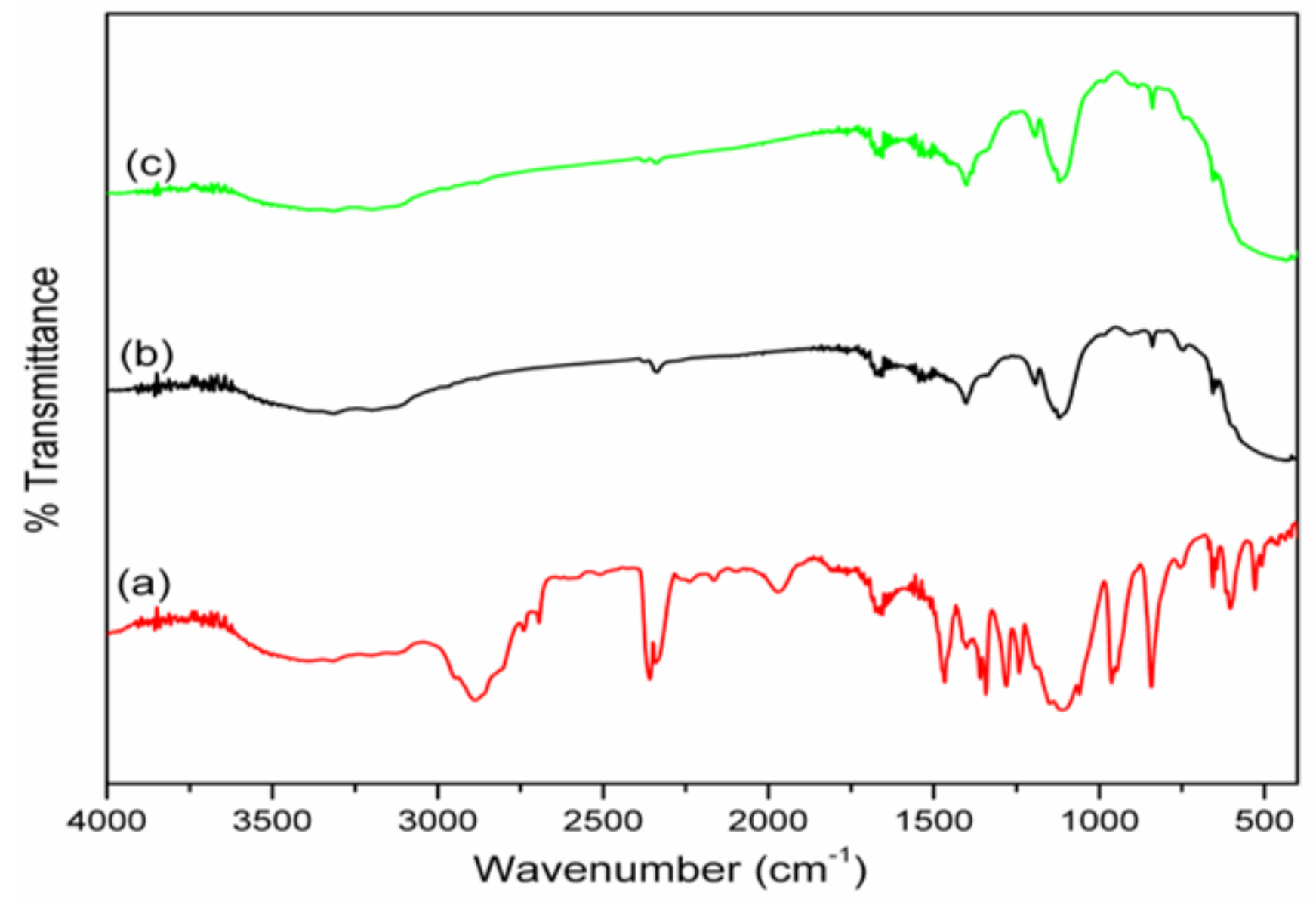

Figure 9

FTIR spectra of (a) PEG (b) PEG Capped ZnO (c) Silver-Doped ZnO Nanoparticles. 


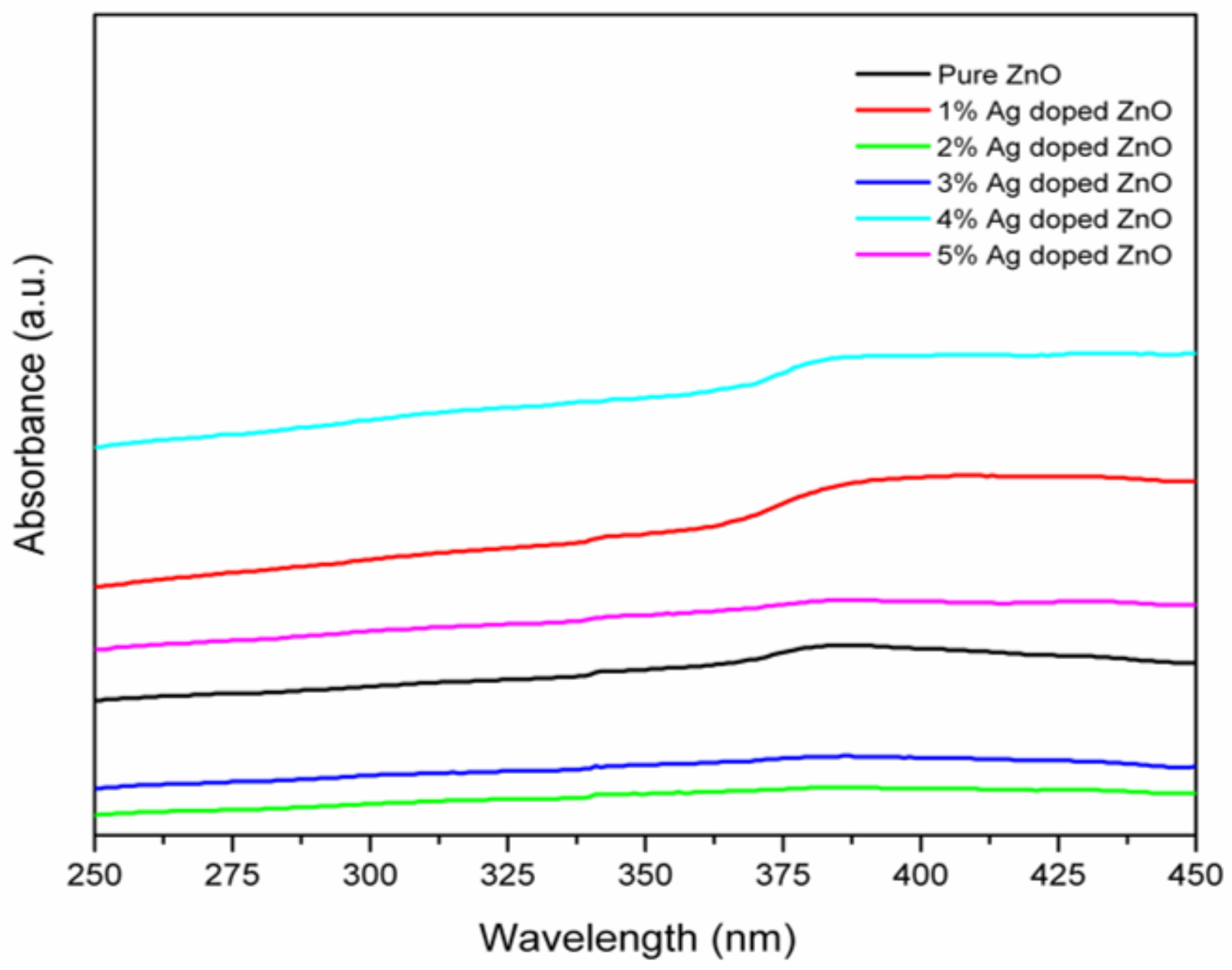

Figure 10

Absorption spectra of the PEG capped pure ZnO and Silver (1-5\%) doped ZnO nanoparticles. 


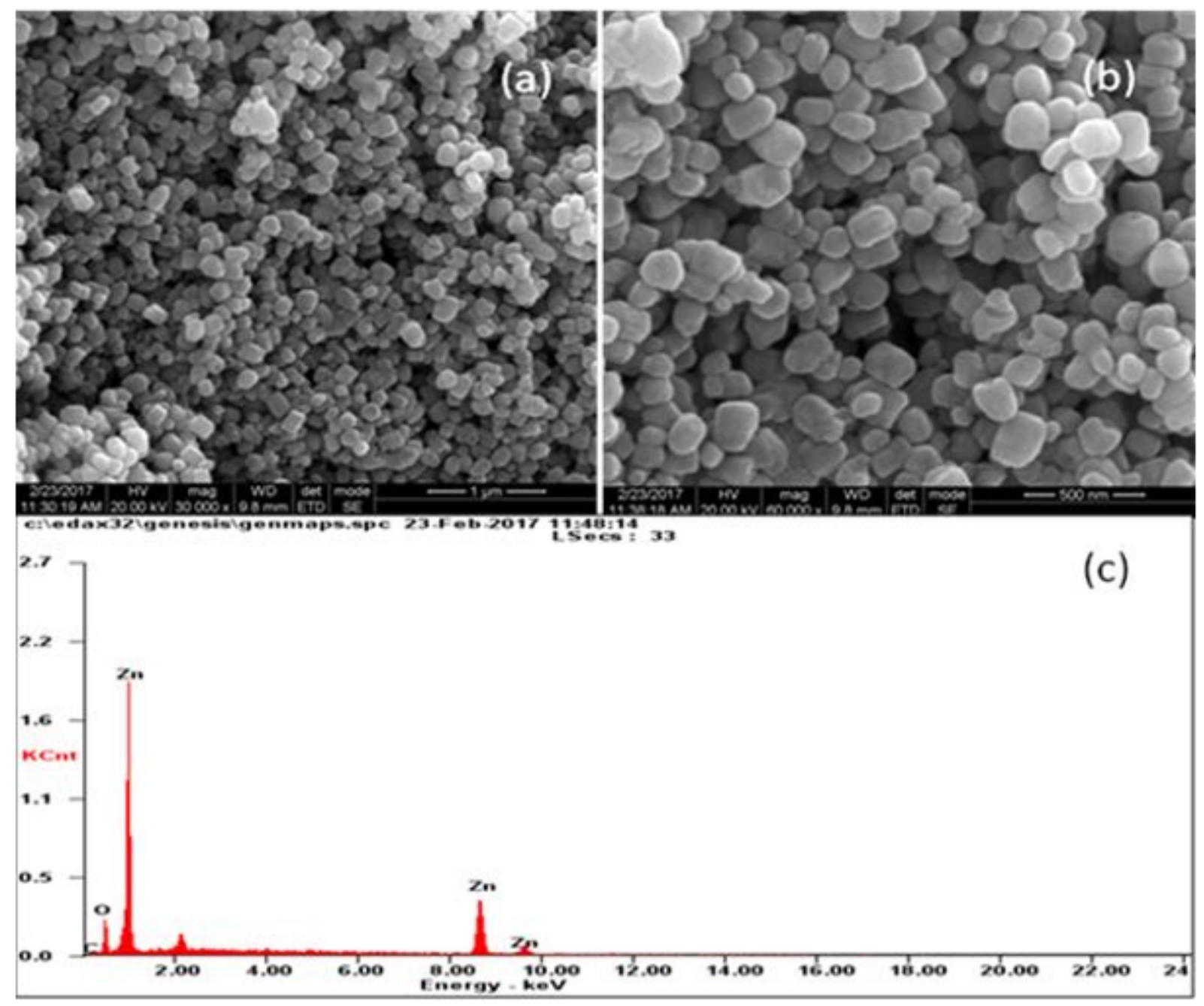

Figure 11

(a-c) SEM and EDAX of ZnO nanoparticles 


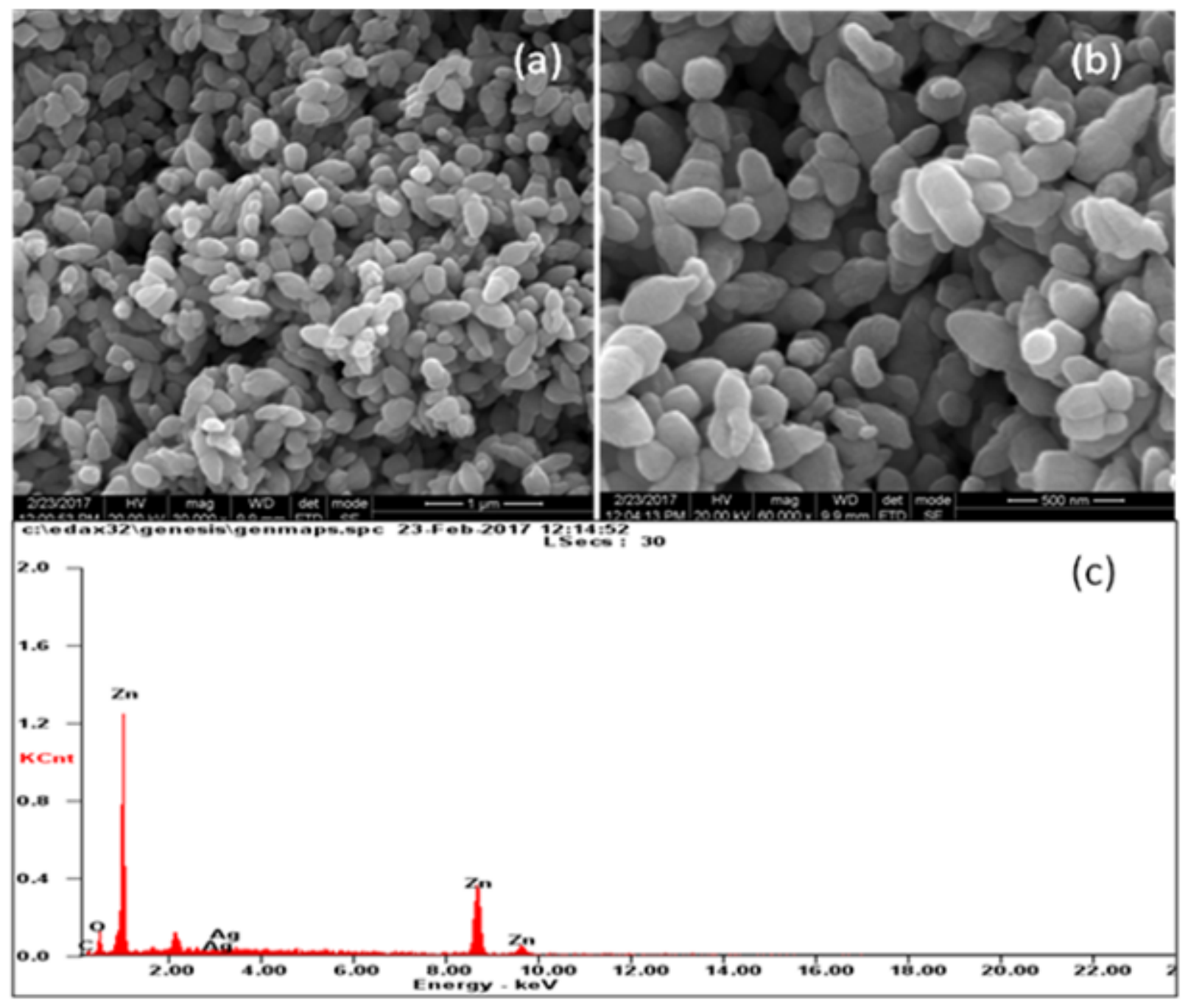

Figure 12

(a-c) SEM and EDAX of silver doped ZnO nanoparticles. 


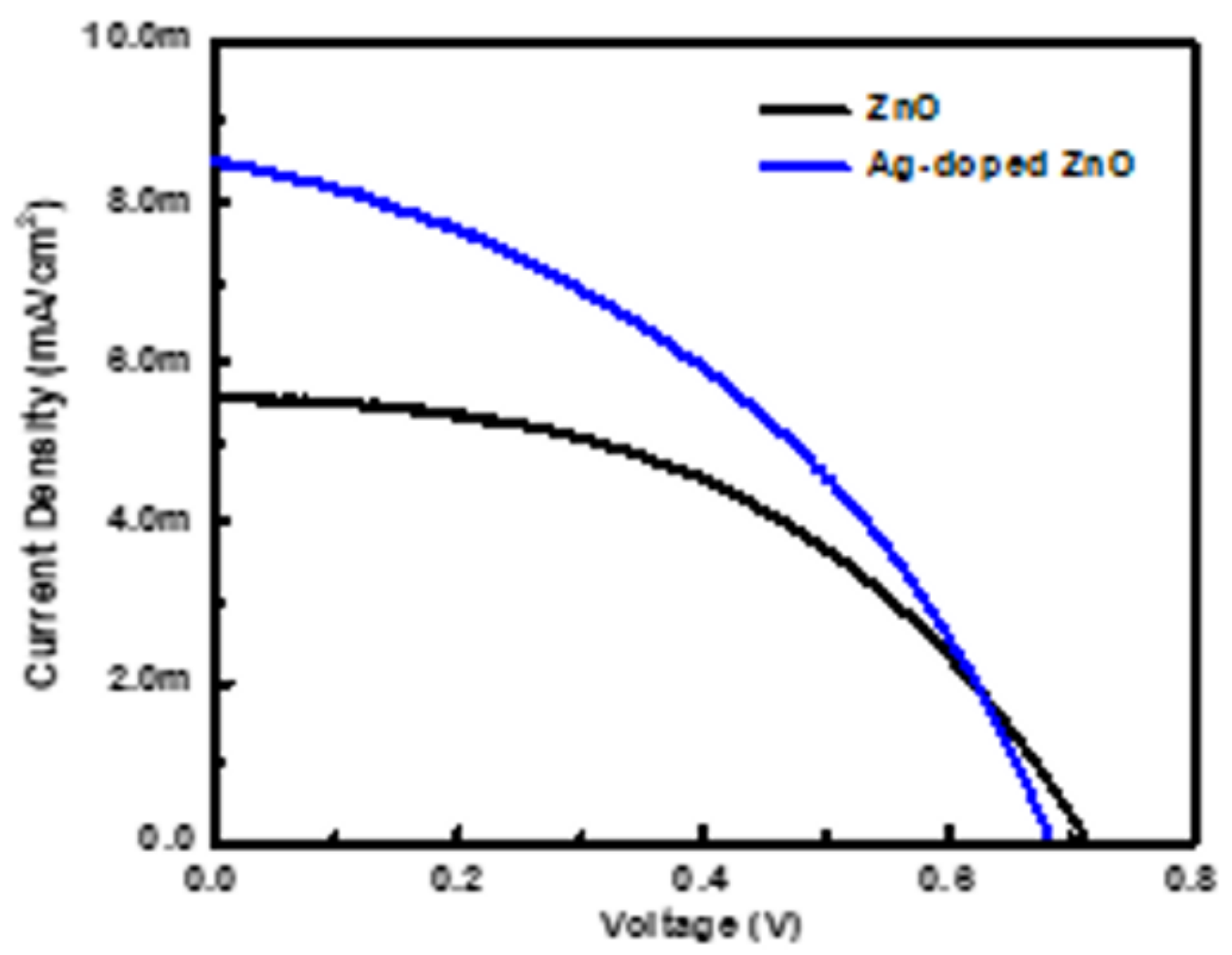

Figure 13

Current-Voltage characteristics of $\mathrm{ZnO}$ and Ag-doped $\mathrm{ZnO}$ solar cells under 1 sun radiation.

\section{Supplementary Files}

This is a list of supplementary files associated with this preprint. Click to download.

- HighlightsESPR.docx 